Vol. 4 No. 2 Juni 2017

\title{
IMPLEMENTASI KEKUATAN EKSEKUTORIAL TERHADAP HAK TANGGUNGAN \\ DALAM RANGKA PENYELESAIAN KREDIT MACET BERDASARKAN AKTA YANG TELAH DIBUAT OLEH NOTARIS
}

\author{
Fadhilah Sundah, Jawade Hafidz ${ }^{* *}$ \\ Mahasiswa Program Magister (S2) Kenotariatan Fakultas Hukum UNISSULA, Semarang email: \\ adhilazz@yahoo.com \\ Dosen Fakultas Hukum UNISSULA, Semarang
}

\begin{abstract}
The mortgage right is one of the guarantee institutions in Indonesia that is often used in the provision of credit agreements whose arrangements are regulated in Law No. 4 of 1996 on Mortgage Rights. Against a non-performing loan, the mortgage holds stronger executorial strength compared to other guarantees in general. Registration of mortgages can only be done by the Land Acquisition Authority (PPAT) who has the authority as mandated by law with the establishment of a Deed of Assignment Rights (APHT) and registered by the relevant official to the National Land Agency (BPN) with the terms and times that have been determined as well. The existence of a bad credit is also caused by the debtor who has bad faith in installing the credit and expected a self-know system to know the financial history of debtors to the bank more thoroughly in conducting credit analysis.
\end{abstract}

Keywords: The power of ekskutorial, mortgage rights.

\section{PENDAHULUAN}

Seiring dengan perkembangan ekonomi yang ada di Indonesia, upaya perkreditan melalui lembaga perbankan lebih sering melaksanakan adanya suatu pemberian kredit dari kreditor kepada debitor. Pemberian kredit ini dilakukan dengan pembuatan perjanjian pokok terlebih dahulu yang diberikan oleh kreditor kepada debitor atas kesepakatan bersama. Perjanjian pokok dapat dilakukan dengan perjanjian di bawah tangan atau dengan akta otentik yang dibuat oleh perjabat yang berwenang dalam hal ini adalah notaris. Dalam pemberian kredit pihak bank biasanya akan melakukan analisis kredit sesuai dengan prinsip perkreditan dengan tujuan untuk mengetahui riwayat kondisi keuangan debitor dan alasan debitor untuk meminjam kredit.

Dalam hal untuk mengurangi risiko kredit yaitu dengan adanya suatu wanprestasi atau kredit macet yang dilakukan oleh debitor maka mayoritas pihak kreditor akan meminta sebuah jaminan kepada debitor. Jaminan yang paling sering digunakan dalam hal pemberian kredit adalah berupa tanah atau tanah dan bangunan, yang diikat dengan hak tanggungan berdasarkan peraturan perundang-undangan yang berlaku.

Hak tanggungan diatur dalam UndangUndang Nomor 4 Tahun 1996 tentang Hak Tanggungan yang mempunyai kekuatan eksekutorial yang tetap dan kuat dalam hal pelaksanaan eksekusinya, selain pelaksanaan eksekusi yang mudah alasan lain menggunakan hak tanggungan adalah adanya suatu kedudukan yang diutamakan kepada para kreditor yang memiliki hak tanggungan tersebut. Dalam Pasal 51 Undang-Undang Nomor 5 Tahun 1960 bahwa hakhak yang dapat dibebani oleh hak tanggungan yaitu hak milik, hak guna bangunan dan hak guna usaha.

Hak tanggungan berupa tanah yang juga termasuk benda yang ada di atasnya bertujuan sebagai pelunasan atas suatu hutang tertentu, yang menimbulkan hak dan kewajiban yang harus 
dipenuhi oleh masing-masing pihak yang bersangkutan. Dimana pihak debitor wajib untuk melakukan angsuran atau pelunasan hutang kepada kreditor sesuai dengan waktu yang telah ditentukan dan disepakati bersama. Namun, tidak jarang bahwa debitor telah melakukan wanprestasi terhadap prestasinya yaitu adanya suatu alasan yang menyebabkan debitor tidak sanggup untuk melunasi hutangnya sehingga terjadilah kredit macet.

\section{METODE PENELITIAN}

Metode penelitian yang digunakan dalam penulisan tesis ini adalah menggunakan metode yuridis sosiologis, artinya mengemukakan kenyataan hukum yang dijalani di lapangan atau suatu pendekatan yang berpangkal pada pemisahan mengenai hal yang bersifat yuridis serta kenyataan yang ada. Spesifikasi penelitian yang digunakan juga bersifat deskriptif dengan tujuan untuk menggambarkan suatu gejala, peristiwa, kejadian yang terjadi saat sekarang. Penelitian deskriptif memusatkan perhatian kepada masalah-masalah actual sebagaimana adanya pada saat menggambarkan peristiwa dan kejadian yang menjadi pusat perhatian tanpa memberikan perlakuan khusus terhadap peristiwa tersebut. Dalam hal ini obyek penelitian adalah masyarakat, lembaga masyarakat yang berwenang dan lain sebagainya. Hasil penelitian deskriptif ini kemudian dianalisa secara sistematis untuk mendapatkan jawaban dari permasalahan yang ada dalam penelitian ini.

Jenis dan sumber data yang digunakan dengan data primer atau mengolah bahan pustaka yang mempunyai kekuatan yang mengikat secara yuridis dan data sekunder melalui informasi dari pihak yang berkaitan dengan judul penulis. Teknik pengumpulan data menggunakan alat pengumpul data tertentu yang berpedoman kepada jenis datanya melalui studi kepustakaan maupun data yang diperoleh dari pihak-pihak terkait melalui wawancara. Untuk selanjutnya dilakukan analisis data dengan metode analisis kualitatif yang dianalisa secara interpretatif menggunakan teori maupun hukum positif yang telah dituangkan kemudian secara deduktif ditarik kesimpulan untuk menjawab permasalahan yang ada. ${ }^{1}$

\section{HASIL PENELITIAN DAN PEMBAHASAN}

Salah satu risiko utama yang dihadapi oleh bank dalam kegiatan pemberian kredit adalah terjadinya kredit macet atas pemberian pembiayan atau kredit yang dilakukan oleh bank kepada nasabahnya. Untuk mencegah hal tersebut maka bank dalam melakukan pemberian kredit harus benar-benar meneliti dengan secara seksama terhadap kemampuan dari nasabahnya untuk mengembalikan kredit yang diberikan oleh bank. Oleh karena itu, sebelum bank memberikan kredit kepada calon debitor setiap pegawai bank yang ditugasi untuk itu akan melakukan analisis kredit berdasarkan pada prinsip-prinsip perbankan, yaitu :

1. Character (Karakter)

Karakter sangat menyangkut sifat debitor yang harus mempunyai itikad baik dan komitmen tinggi untuk mengembalikan seluruh kewajiban sesuai dengan perjanjian yangtelah ditandatangani bersama antara pihak debitor dan pihak bank. Karakter dari debitor tidak diragukan lagi dan tidak bercacat cela. Sebagai gambaran ada beberapa sifat calon debitor yang akan menentukan karakter seperti :
a. Usia, pendidikan, status, kesehatan;
b. Pengendalian emosi;
c. Pergaulan, lingkungan, relasi, sosialisasi;
d. Hobi dan kegemaran baik/buruk;
e. Kebiasaan baik/buruk;
f. Tanggung jawab terhadap kewajiban kepada semua pihak yang berhubungan;
g. Dan lain-lain.

2. Capital (Modal)

Modal usaha debitor, modal awal, modal utang, laba, dan dana cadangan, akan menentukan besarnya presentase usaha yang dimiliki oleh debitor.

3. Capacity (Kemampuan)

Analisis kemampuan manajemen untuk mengelola suatu usaha sehingga debitor dapat menghasilkan laba dan dapat membayar

\footnotetext{
${ }^{1}$ Bambang Sugugono, Metode Penelitian Hukum, PT Raja Grafindo Persada, Jakarta, 2003, hlm. 119.
} 
seluruh kewajiban di masa sekarang dan masa yang akan datang.

4. Collateral(Jaminan)

Penilaian jaminan dilakukan untuk melihat sejauh mana tingkat kemudahan diperjualbelikannya obyek jaminan (marketable), semakin mudah asset tersebut diperjualbelikan, tingkat risiko bank semakin berkurang. Dan besarnya nilai jaminan 125\% mengcover seluruh pinjaman. Jaminan hanya berfungsi dan bersifat sebagai solusi terakhir (second wayout) apabila debitor bermasalah tidak dapat mengembalikan kewajiban pinjaman.

\section{Condition (Kondisi)}

Analisis terhadap "kondisi" meliputi terhadap ekonomi (mikro dan makro) baik nasional, regional maupun internasional, politik, perundang-undangan, dan lain-lain. Pengaruhnya terhadap usaha debitor yang sedang berjalan dilihat untuk masa sekarang dan masa yang akan datang.

Apabila debitor tidak jujur, curang, ataupun incompetence, maka kredit tidak akan berhasil tanpa perlu memperhatikan faktor-faktor lainnya. Berkaitan dengan hal tersebut pula, biasanya bank meminta hak tanggungan yang dapat dikatakan bahwa hak tanggungan tersebut merupakan salah satu jaminan kredit yang paling kuat. Hal tersebut disebabkan karena keutamaan dari hak tanggungan terletak dalam pelaksanaan eksekusi yang dimiliki oleh hak tanggungan itu sendiri, karena mudah dan pasti dalam pelaksanaan eksekusinya. Hak tanggungan diatur dalam Undang-Undang Nomor 4 Tahun 1996 tentang Hak Tanggungan. Selain itu, hak tanggungan memberikan kedudukan diutamakan kepada kreditor tertentu terhadap kreditor-kreditor lain. Kreditor tertentu yang dimaksud adalah yang memperoleh atau yang menjadi pemegang hak tanggungan.Bahwa jika tejadi cidera janji, kreditor pemegang hak tanggungan berhak menjual melalui pelelangan umum tanah yang dijadikan jaminan menurut ketentuan perundang-undangan yang bersangkutan, dengan hak mendahulu daripada kreditor-kreditor yang lain.

Adapula dalam pemberian hak tanggungan, pemberi hak tanggungan wajib hadir di hadapan
Pejabat Pembuat Akta Tanah. Apabila karena suatu sebab pemberi hak tanggungan tidak dapat hadir, maka ia wajib menunjuk pihak lain sebagai kuasa dengan membuat Surat Kuasa Membebankan Hak Tanggungan (untuk selanjutnya disebut SKMHT) yang berbentuk akta autentik. Pembuatan SKMHT dapat dilakukan oleh Notaris ataupun Pejabat Pembuat Akta Tanah yang keberadaannya sampai pada wilayah kecamatan dalam rangka memudahkan pelayanan kepada pihak-pihak yang memerlukan.Hak tanggungan baru akan lahir pada saat telahh dibukukannya dalam buku tanah di Kantor Pertanahan. Oleh karena itu kepastian mengenai saat didaftarkannya hak tanggungan tersebut adalah sangat penting bagi kreditor. Saat tersebut bukan saja menentukan kedudukannya yang diutamakan peringkatnya dalam hubungannya dengan kreditor-kreditor lain yang juga pemegang hak tanggugan, dengan tanah yang sama sebagai jaminannya.

Dalam penjelasan Undang-Undang Hak Tanggungan diterangkan bahwa hak tanggungan merupakan lembaga jaminan hak atas tanah yang kuat, dimana ciri-cirinya adalah :

1. Memberikan kedudukan yang diutamakan atau mendahulu kepada pemegangnya.

2. Selalu mengikuti objek yang dijaminkan dalam tangan siapa pun objek itu berada.

3. Memenuhi asas spesialitas dan publisitas sehingga dapat mengikat pihak ketiga dan memberikan kepastian hukum kepada pihakpihak yang berkepentingan.

4. Mudah dan pasti pelaksanaan eksekusinya.

Seperti yang telah dijelaskan di atas, pemberi hak tanggungan wajib hadir dihadapan Pejabat Pembuat Akta Tanah. Jika karena suatu sebab tidak dapat hadir sendiri, ia wajib menunjuk pihak lain sebagai kuasanya, dengan Surat Kuasa Membebankan Hak Tanggungan (SKMHT) yang berbentuk akta autentik. Pembuatan SKMHT selain dibuat oleh notaris juga dapat dibuat oleh PPAT yang keberadaannya sampai pada wilayah kecamatan dalam rangka memudahkan pelayanan kepada pihak-pihak yang memerlukan.

Dalam kenyataannya, terdapat beberapa notaris yang tidak melaksanakan pembuatan Akta Pemberian Hak Tanggungan (APHT) setelah 
dilaksanakannya SKMHT. Pada kredit tertentu misalnya kredit mikro yang pinajamannya kurang dari 50 juta, adakalanya pengikatan jaminan hanya sebatas pada SKHMT saja tanpa ditingkatkan ke $\mathrm{APHT}$, hingga berakhirnya masa kredit. Atas hal tersebut dapat dianalisis pada Pasal 15 ayat (2) UU No. 4 Tahun 1996 tentang Hak Tanggungan yang menjelaskan bahwa kuasa untuk membebankan hak tanggungan tidak dapat ditarik kembali atau tidak dapat berakhir oleh sebab apapun juga kecuali karena kuasa tersebut telah dilaksanakan atau karena telah habis jangka waktunya sebagaimana dimaksud pada Pasal 15 ayat (3) dan ayat (4) UUHT.

Selanjutnya apabila kita lihat pada Pasal 15 ayat (3) dan ayat (4) Undang-Undang Hak Tanggungan, diatur bahwa SKMHT wajib diikuti dengan pembuatan Akta Pemberian Hak Tanggungan yaitu untuk tanah yang telah terdaftar maupun untuk tanah yang belum terdaftar selambat-lambatnya 1 bulan setelah pemberian SKMHT. Pengecualian dari ketentuan tersebut adalah untuk janis-jenis tertentu. Jenisjenis kredit ini sendiri diatur dalam Peraturan Menteri Negara Agraria/Kepala BPN Nomor 4 Tahun 1996 tentang Penetapan Batas Waktu Penggunaan Surat Kuasa Membebankan Hak Tanggungan Untuk Menjamin Pelunasan KreditKredit Tertentu.

Namun dalam kenyataannya selain untuk kredit-kredit tersebut yang telah disebutkan di atas, apabila pembuatan SKMHT saja tanpa diikuti dengan pembuatan APHT, maka hak tanggungan yang dijadikan jaminan dalam pemberian kredit menjadi tidak sah dikatakan sebagai hak tanggungan atau hak tanggungan tersebut menjadi batal, sehingga pemberian kredit tidak dapat dilaksanakan. Tetapi untuk hak tanggungan yang sudah dijaminkan dan sudah dalam pemberian proses kredit yang dibebankan dengan SKMHT tetapi tetap tidak dibuatkan APHT, maka kekuatan eksekutorial terhadap hak tanggungan tersebut menjadi tidak ada, karena tidak sahnya pembebanan hak tanggungan yang dilakukan.

Selain hal tersebut terdapat juga kasus mengenai pelaksanaan pembebanan hak tanggungan terhadap tanah yang belum bersertipikat dalam prakteknya tidak pernah dilakukan bank dengan cara membuat APHT secara langsung terhadap tanah-tanah yang belum bersertipikat. Bank dalam hal ini hanya sebatas membuat surat kuasa membebankan hak tanggungan (selanjutnya disebut SKMHT). Pertimbangan hukum tidak dibuatnya APHT terhadap tanah-tanah yang belum didaftar oleh karena terdapat kemungkinan hak-hak atas tanah tersebut belum jelas kepemilikannya. Notaris atau PPAT dalam prakteknya selalu membuatkan SKMHT sesuai dengan Pasal 15 ayat (4) UndangUndang Hak Tanggungan untuk mengikat jaminan atas tanah-tanah yang belum bersertipikat yang akan dijadikan agunan. Namun hal inilah yang menjadi kendala karena proses pensertipikatannya memerlukan jangka waktu 3 (tiga) bulan bahkan bisa 1 (satu) tahun. Menghadapi permasalahan terjadinya kredit belum dilunasi dengan agunan tanah yang belum bersertipikat sedangkan debitur telah meninggal dunia dan meninggalkan ahli waris, maka ada beberapa cara penyelesaian yang dilakukan oleh bank, yaitu jika kredit telah jatuh tempo, maka kredit dicover oleh asuransi kredit. Jika kredit telah jatuh tempo dan asuransi kreditnya telah kadaluarsa, maka akan ditagih sampai lunas kepada ahli warisnya dengan melakukan pendekatan kekeluargaan dengan menawarkan keringanan bunga pinjaman, meminta ahli waris yang bersangkutan untuk melakukan penjualan dibawah tangan atas obyek jaminan tersebut.

Sebagai contoh lainnya adalah dalam bencana alam gunung merapi yang meletus pada tahun 2010, kondisi seperti halnya erupsi gunung merapi merupakan kejadian diluar dugaan sebelumnya yang berakibat debitor kesulitan membayar angsuran kreditnya dan ada pula tanah yang sudah dijadikan hak tanggungan hilang akibat adanya bencana tersebut. Hal tersebut menjadi risiko pihak bank atas kredit macet pasca bencana erupsi Gunung Merapi. Biasanya suatu jaminan akan diberikan suatu pertanggungan atau asuransi guna mengurangi risiko yang akan terjadi. Dalam hal ini asuransinya yang berfungsi untuk mengurangi masalah kredit tersebut dan adanya suatu restrukturisasi kredit yaitu dengan melakukan pengurangan plafond kredit. Dimana dapat dikatakan bahwa walaupun hak tanggungan 
tersebut musnah karena erupsi letusan Gunung Merapi maka kredit tersebut tetap berjalan dan jaminan hak tanggungan yang musnah digantikan dengan adanya suatu asuransi dan dilakukannya pengurangan kredit, sehingga hak tanggungan tersebut tetap mempunyai kekuatan eksekutorialnya.

Terdapat juga masalah mengenai tanah yang dijadikan obyek hak tanggungan yang terkena bencana alam berupa gempa bumi atau longsor, hal ini menimbulkan masalah karena obyek jaminan hak tanggungan menjadi musnah. Kedudukan sertipikat hak tanggungan pun menjadi tidak jelas, dan bagi pemegang hak tanggungan yaitu bank akan mengalami kerugian jika debitor tidak bisa melunasi hutang kreditnya, bank pun tidak bisa mengeksekusi jaminan karena hak tanggungan yang berupa tanah sudah lenyap akibat peristiwa tanah longsor. Dalam Pasal 18 ayat (1) Undang-Undang Hak Tanggungan sendiripun dijelaskan bahwa hak tanggungan hapus karena hapusnya utang yang dijamin dengan hak tanggungan, dilepaskannya hak tanggungan oleh pemegang hak tanggungan, pembersihan hak tanggungan berdasarkan penetapan peringkat oleh Ketua Pengadilan Negeri dan hapusnya hak atas tanah yang dibebani hak tanggungan.

Berkaitan dengan hapusnya hak tanggungan karena suatu keadaan overmarcht yang mengakibatkan obyek hak tanggungan musnah tidak diatur dalam Pasal 18 Undang-Undang Hak Tanggungan maupun dalam rumusan pasal lain pada Undang-Undang Hak Tanggungan. Keadaan demikian akan menimbulkan kekosongan norma (leemten van norm) dalam Undang-Undang Hak Tanggungan. Sehingga dapat dikatakan adanya suatu cacat hukum administratif, oleh karena itu kekuatan eksekutorial sertipikat hak tanggungan yang obyeknya musnah karena bencana alam adalah hapus. Hapusnya kekuatan eksekutorial sertipikat hak tanggungan disebabkan oleh hapusnya hak tanggungan karena obyek hak tanggungan telah musnah terkena bencana alam. Perlindungan hukum bagi kreditur selaku pemegang sertipikat hak tanggungan dalam hal musnahnya seluruh obyek hak tanggungan adalah perlindungan hukum yang bersifat preventif dan represif. Perlindungan hukum preventif dilakukan dengan memasukkan klausula bahwa obyek hak tanggungan tersebut harus diasuransikan dalam APHT, sehingga pihak kreditur dan debitur memiliki kewajiban untuk mengasurnasikan obyek hak tanggungan tersebu, sehingga jika terjadi suatu peristiwa bencana alam yang mengakibatkan musnahnya obyek hak tanggungan, maka pihak asuransi yang akan membayar kerugian yang timbul akibat peristiwa tersebut. Perlindungan represif yang dapat diberikan kepada kreditur selaku pemegang sertipikat hak tanggungan adalah pembayaran uang klaim kepada kreditur oleh pihak asuransi sebagai pengganti pembayaran kredit debitur, bila terjadi suatu peristiwa bencana alam yang mengakibatkan musnahnya obyek hak tanggungan.

Dalam praktek terdapat pula kasus yaitu jaminan hak tanggungan yang diberikan kepada bank bukan milik debitor melainkan milik pihak ketiga. Pihak ketiga di sini adalah seperti orang tua, anak, saudara, atau tanah warisan, dll, seiring berjalannya pelaksanaan kredit kemudian timbul masalah yang dialami oleh debitor yakni dengan adanya kredit macet, tetapi pemilik jaminan tidak rela apabila tanah miliknya tersebut di eksekusi oleh bank. Hal tersebut tidak berpengaruh terhadap pelaksanaan eksekusi dengan langsung menghentikan eksekusi tersebut, karena dalam awal tandatangan perjanjian kredit pihak pemilik jaminan juga ikut bertandatangan dalam perjanjian kredit itu sendiri, yang tentunya pihak bank sudah menerangkan kepada pihak-pihak yang bersangkutan bagaimana apabila akhirnya jaminan hak tanggungan tersebut harus dieksekusi. Sehingga kekuatan eksekutorial dari pelaksanaan hak tanggungan apabila jaminan yang ditanggungkan bukan milik debitor adalah tetap ada dan harus berjalan sesuai dengan ketentuan perjanjian dan peraturan yang berlaku.

Pelaksanaan eksekusi hak tanggungan yang secara mudah dan pasti dalam hak tanggungan maka pada sertipikat hak tanggungan dicantumkanlah irah-irah yang berbunyi "DEMI KEADILAN BERDASARKAN KETUHANAN YANG MAHA ESA", untuk memberikan kekuatan eksekutorial yang sama dengan putusan pengadilan yang telah mempunyai kekuatan 
hukum tetap, seperti yang telah diatur dalam ketentuan Pasal 14 ayat (2) dan ayat (3) UndangUndang Hak Tanggungan yang menyatakan bahwa "Sertipikat Hak Tanggungan sebagaimana dimaksud pada ayat (1) memuat irah-irah dengan kata-kata "DEMI KEADILAN BERDASARKAN KETUHANAN YANG MAHA ESA".Dengan demikian hak tanggungan mempunyai kekuatan eksekutorial yang sama dengan putusan pengadilan yang telah memperoleh kekuatan hukum tetap dan berlaku sebagai pengganti grosse akta hypotheek sepanjang mengenai hak atas tanah. Eksekusi untuk implementasi kekuatan eksekutorial hal tanggungan maka dalam UUHT terdapat 2 (dua) cara untuk pelaksanaannya, yaitu dengan eksekusi langsung yang mana eksekusi langsung ini disebut juga dengan istilah"parate eksekusi" (parate executie), dimana eksekusi dapat dilakukan secara langsung oleh kreditor tanpa perlu meminta adanya fiat atau penetapan atau bantuan dari pengadilan.Hal ini terlihat dari bunyi Pasal 6 Undang-Undang Hak Tanggungan itu sendiri yaitu "pemegang Hak Tanggungan pertama mempunyai hak untuk menjual objek Hak Tanggungan atas kekuasaan sendiri melalui pelelangan umum", dimana pasal 6 tersebut memberikan kewenangan kepada pemegang Hak Tanggungan pertama untuk menjual atas kekuasaan sendiri. Serta eksekusi melalui titel eksekutorial yang dilakukan dengan merujuk kepada ketentuan yang terdapat dalam Pasal 224 Het Herziene Indonesisch Reglement (HIR)/258 Reglement tot Regeling van het Rechtswezen in de Gewesten Buiten Java en Madura (RBg). Isi dari pasal 224HIR/258RBg menjelaskan bahwa terhadap surat yang dicantumkan irah-irah yang berbunyi "Atas nama Keadilan" sekarang "Demi Keadilan Berdasarkan Ketuhanan Yang Maha Esa" maka surat tersebut mempunyai kekuatan sama dengan putusan hakim yang sudah mempunyai kekuatan pasti atau tetap dan untuk melaksanakan eksekusinya jika tidak ditepati dengan jalan damai, maka menjalankannya dilakukan dengan perintah dan pimpinan Ketua Pengadilan Negeri, yang dalam pegangannya orang berhutang itu diam atau tinggal atau memilih kedudukannya.

Dalam eksekusi terhadap objek hak tanggungan ini kreditor tidak perlu melakukan gugat-menggugat dengan pihak debitor, akan tetapi cukup dengan mengajukan permohonan eksekusi kepada ketua pengadilan dengan melampirkan bukti wanprestasinya debitor yang disertai dengan sertifikat hak tanggungan. Atas dasar itu maka Ketua Pengadilan akan mengeluarkan penetapan eksekusi dan melakukan eksekusi terhadap objek hak tanggungan yang dimohonkan untuk di eksekusi. Eksekusi akan dilaksanakan atas perintah dan dengan pimpinan Ketua Pengadilan Negeri tersebut, melalui pelelangan umum yang dilakukan oleh Kantor Pelayanan Kekayaan Negara dan Lelang (KPKNL).

Oleh karena itu, implementasi kekuatan eksekutorial yang dimiliki oleh sertifikat hak tanggungan dalam pelaksanaan eksekusi hak tanggungan terhadap akta yang telah dibuat oleh notaris adalah tetap mempunyai kekuatan hukum yang tetap. Karena dalam pelaksanaan eksekusi melalui pelaksanaan lelang adalah sama dengan putusan pengadilan yang telah mempunyai kekuatan hukum tetap. Hal tersebut karena pada sertifikat hak tanggungan telah dicantumkan irahirah yang berbunyi "Demi Keadilan Berdasarkan Ketuhanan Yang Maha Esa". Untuk pelaksanaan dari kekuatan eksekutorial tersebut UndangUndang Hak Tanggungan memberikan 2 (dua) cara yaitu melalui eksekusi secara langsung sesuai dengan ketentuan dalam Pasal 6 Undang-Undang Hak Tanggungan dan melalui titel eksekutorial sebagaimana yang diatur dalam Pasal 20 ayat (1) Undang-Undang Hak Tanggungan. Serta walaupun adanya tuntutan dari pihak ketiga dalam hal ini pemilik jaminan, pelaksanaan eksekusi pun juga tetap dilaksanakan seperti yang telah ditandatangani pihak-pihak yang bersangkutan karena telah diperjanjikan pada awal perjanjian kredit, baik pada debitor maupun baik pada penjamin. Namun dalam kondisi tertentu untuk kekuatan eksekutorial hak tanggungan dalam hal adanya bencana alam atau tanah longsor maka hak tanggungan tersebut menjadi hapus karena musnahnya hak tanggungan yang dijadikan jaminan. Sementara itu, dalam hal pembuatan SKMHT yang tidak diikuti dengan APHT maka kekuatan ekskutorialnya juga menjadi hapus karena tidak sahnya pelaksanaan hak tanggungan yang bersangkutan. 
Dalam pelaksanaan pemberian kredit pasti terjadi hambatan-hambatan yang muncul diantaranya adalah debitor beritikad tidak baik dimana sesuai dengan hasil evaluasi dan identifikasi yang dilakukan oleh kreditor, diketahui bahwa debitor sebetulnya mampu untuk memenuhi kewajibannya untuk menyelesaikan kreditnya kepada bank sebagai kreditor, namun debitor dengan sengaja tidak menyelesaikan masalah kreditnya atau dengan sengaja melarikan diri. Serta, debitor mengalami masalah ekonomi, dimana debitor tidak bisa mengelola usahanya sehingga mengalami kegagalan yang menyebabkan pihak debitor sulit memenuhi kewajibannya untuk menyelesaikan permasalahan kreditnya kepada bank sebagai kreditor.

Oleh karena itu pula perlu dilakukannya penyelesaian kredit yang lebih baik di masa yang akan datang yaitu dengan cara dilakukan dengan rescheduling (penjadwalan kembali) yaitu upaya hukum untuk melakukan perubahan terhadap beberapa syarat perjanjian kredit yang berkenaan dengan jadwal pembayaran kembali atau jangka waktu kredit termasuk tenggang (grace period), jumlah angsuran, bila perlu dengan penambahan kredit. Reconditioning (persyaratan kembali) yaitu melakukan perubahan atas sebagian atau seluruh persyaratan perjanjian, yang tidak terbatas hanya kepada perubahan jadwal angsuran, dan/atau jangka waktu kredit saja, tetapi perubahan kredit tersebut tanpa memberikan tambahan kredit dan restructuring (penataan kembali) yaitu upaya berupa melakukan perubahan syarat-syarat perjanjian kredit berupa pemberian tambahan kredit, atau melakukan konversi atas seluruh atau sebagian kredit menjadi perusahaan, yang dilakukan dengan atau tanpa rescheduling dan/atau reconditioning.

\section{KESIMPULAN}

Implementasi kekuatan eksekutorial terhadap hak tanggungan dalam rangka penyelesaian kredit macet berdasarkan akta yang telah dibuat oleh notaris adalah mempunyai kekuatan hukum yang tetap. Dalam pelaksanaan eksekusi melalui pelaksanaan lelang adalah sama dengan putusan pengadilan yang telah mempunyai kekuatan hukum tetap. Hal tersebut karena pada sertifikat hak tanggungan telah dicantumkan irah-irah yang berbunyi "Demi Keadilan Berdasarkan Ketuhanan Yang Maha Esa". Tetapi untuk keadaan tertentu kekuatan eksekutorial hak tanggungan dalam hal adanya bencana alam atau tanah longsor maka hak tanggungan tersebut menjadi hapus karena musnahnya hak tanggungan yang dijadikan jaminan. Sementara itu, dalam hal pembuatan SKMHT yang tidak diikuti dengan APHT maka kekuatan ekskutorialnya juga menjadi hapus karena tidak sahnya pelaksanaan hak tanggungan yang bersangkutan.

Hambatan yang terjadi dalam proses penyelesaian kredit macet yaitu debitor beritikad tidak baik dimana sesuai dengan hasil evaluasi dan identifikasi yang dilakukan oleh kreditor, diketahui bahwa debitor sebetulnya mampu untuk memenuhi kewajibannya untuk menyelesaikan kreditnya kepada bank sebagai kreditor, namun debitor dengan sengaja tidak menyelesaikan masalah kreditnya atau dengan sengaja melarikan diri. Serta, debitor mengalami masalah ekonomi, dimana debitor tidak bisa mengelola usahanya sehingga mengalami kegagalan yang menyebabkan pihak debitor sulit memenuhi kewajibannya untuk menyelesaikan permasalahan kreditnya kepada bank sebagai kreditor.

Serta Penyelesaian kredit macet yang harus dilakukan di masa yang akan datang adalah tetap mengacu pada Undang-Undang Nomor 10 Tahun 1998 tentang Perubahan Atas Undang-Undang Nomor 7 Tahun 1992 tentang Perbankan, 26 Peraturan Bank Indonesia Nomor 14/ 15 /PBI/2012 tentang Penilaian Kualitas Aset Bank Umum dan ketentuan pada pihak perbankan sendiri. Karena penyelesaian kredit macet yang dilakukan pada saat ini yaitu dengan menggunakan eksekusi jaminan dengan pelelangan oleh Pengadilan Negeri dan KPKNL sudah dirasakan cukup efesien, sebab bank dalam memilih jaminan utang suatu perkreditan, memilih suatu jaminan yang dapat dieksekusi dengan kekuatan hukum yang tetap yaitu dengan hak tanggungan, yang mudah dalam pelaksanaan eksekusinya dan memberikan kepastian hukum kepada pihak-pihak yang berkepentingan. 


\section{SARAN}

Penegak hukum yang berhubungan dengan pelaksanaan eksekusi harus bisa menegakkan Undang-Undang Hak Tanggungan sehingga para kreditor pemegang Hak Tanggungan dapat memanfaatkan hak eksekusi tersebut dengan mudah dalam rangka menyelesaikan kredit macet. Selain itu, Ketua Pengadilan Negeri seharusnya dapat memberikan keputusan "dapat dilaksanakan terlebih dahulu" eksekusi hak tanggungan tersebut. Serta seharusnya dalam melakukan pemberian kredit, kreditor harus benar-benar menganalisa riwayat keuangan debitor dengan diadakannya suatu sistem informasi kredit yang dimiliki oleh Bank Indonesia sebagai pihak perbankan yang kedudukannya paling tinggi dan untuk penyelesaian kredit macet yang saat ini dilakukan dengan langkah eksekusi hak tanggungan, hal tersebut harus dipertahankan dan dikoordinisir dengan baik, agar pihak-pihak yang melaksanakan eksekusi mudah dalam pelaksanaan eksekusinya.

\section{DAFTAR PUSTAKA}

Habib Adjie, 2000, Hak Tanggungan sebagai Lembaga Jaminan Atas Tanah, Mandar Maju, Bandung.

Bambang Sugugono. 2003. Metode Penelitian Hukum. PT Raja Grafindo Persada. Jakarta.

Boedi Harsono, 1996, Konsepsi Pemikiran Tentang Undang-Undang Hak Tanggungan, Bandung.

Sutan Remy Sjahdeini, 1999, Hak Tanggungan Asaz-Asaz, Ketentuan-Ketentuan Pokok dan Masalah Yang Dihadapi Oleh Perbankan (Suatu Kajian Mengenai Undang-Undang Hak Tanggungan), Bandung: Alumni.

Undang-Undang Nomor 4 Tahun 1996 tentang Hak Tanggungan. 